\title{
A Case Study for Tunnel Lighting Lifetime Account
}

\author{
Mehmet Sait CENGIZ* \\ Bitlis Eren University, Department of Technical Vocational School, Bitlis \\ (ORCID: 0000-0003-3029-3388)
}

\begin{abstract}
A lighting device is required to provide minimum lighting level during the operating time. Contamination on lighting device causes luminous flux to be lost in lamp and structural imperfections to be formed on the surface of optical elements. This deficiency in the performance of lighting makes maintenance of lighting devices necessary. This effect formed by the common effect of various parameters and implemented periodically is called maintenance factor. Maintenance factor varies by lighting system, environmental conditions and features of luminaires. In this study, calculation of maintenance factors by years and change of lighting levels by different maintenance factors have been analyzed for high-pressure sodium vapour luminaries in tunnel lighting. Accordingly, increasing the maintenance factor used as multiplier in performance calculations will decrease the energy consumed. Therefore, increasing the Maintenance Factor increases the lighting efficiency.
\end{abstract}

Keywords: Efficiency, Lighting, Maintenance factor, Tunnel lighting.

\section{Tünel Aydınlatma Ömür Hesabı İçin Bir Vaka Çalışması}

\begin{abstract}
Özet
Bir aydınlatma cihazı işletim süresi boyunca asgari aydınlatma seviyesini sağlamalıdır. Aydınlatma cihazındaki kirlenme, lambadaki ışık akısının kaybolmasına ve optik elemanların yüzeyinde yapısal kusurların oluşmasına neden olur. Aydınlatma performansındaki bu eksiklik aydınlatma cihazlarının bakımını gerekli kılar. Çeşitli parametrelerin ortak etkisi ile oluşan ve periyodik olarak uygulanan bu etki bakım faktörü olarak adlandırılır. Bakım faktörü aydınlatma sistemine, çevresel koşullara ve aydınlatma armatürlerinin özelliklerine göre değişir. $\mathrm{Bu}$ çalışmada tünel aydınlatmasında yüksek basınçlı sodyum buharlı aydınlatma armatürlerinde yıllara göre bakım faktörlerinin hesaplanması ve farklı bakım faktörlerine göre aydınlatma seviyelerinin değişimi incelenmiştir. Buna göre, performans hesaplamalarında çarpan olarak kullanılan bakım faktörünün arttırılması, tüketilen enerjiyi azaltmaktadır. Bu nedenle, Bakım Faktörünü artırmak aydınlatma verimliliğini arttırmaktadır.
\end{abstract}

Anahtar Kelimeler: Verimlilik, Aydınlatma, Bakım faktörü, Tünel aydınlatması.

\section{Introduction}

Lighting level, uniformity and glare restrictions are specified by the standards in lighting systems. Lighting system should be designed as so it would provide all these parameters during the operating time.

The operating conditions of the luminaires and lighting directly affect the lighting efficiency. [1]. The most important reason why luminaries' loss their performance is that luminous transmittance decreases since luminaries are dirty because of environmental $[2,3]$.

As for another reason of the performance loss, efficiency of lamp decreases and the lamp last for shorter time depending on operating time. Since performances of luminaries decrease over the time, performance of the lamp will be described for a specified period of time. This period of time may be maintenance processes such as cleaning the glass of luminaire or replacing the lamp by which performances of the luminaires can be improved as well as it may be renewal of all luminaries at the

*Sorumlu yazar: msaitcengiz@gmail.com

Geliş Tarihi: 12.03.2019, Kabul Tarihi: 11.07.2019 
end of operating time for the luminaries [4-7]. Lighting system could supply minimum lighting, even at the end of the period when it displayed the lowest performance, by including the estimated performance loss in the system performance at design phase. Figure 1 illustrates the graphic of tolerance range belonging to Maintenance Factor $(M F)$ exposed to performance loss.

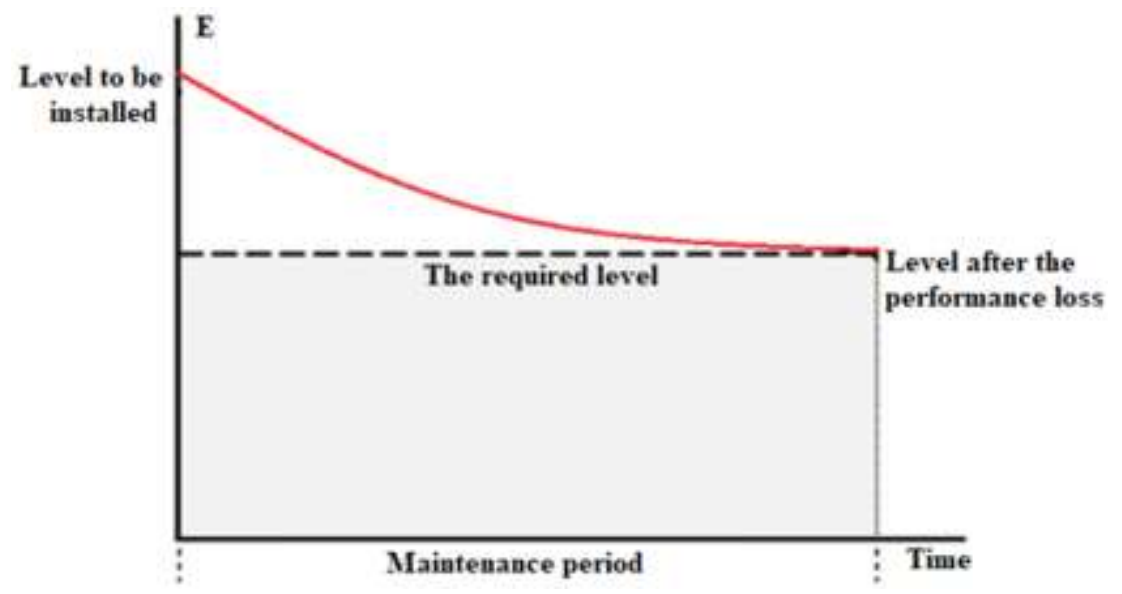

Figure 1. Graphic of tolerance range belonging to $M F$ exposed to performance loss

MF is a parameter specifying performance ratio to be supplied by lighting system at the end of period depending on beginning of the period. Maintenance factor is described as $80 \%$ for a system for which $20 \%$ of performance loss is estimated at the end of maintenance period. Since MF is used as multiplier in programs of lighting calculation, lighting levels reached by lighting calculations display the values at the end of period. MF varies by technology level of the luminaries. According to CIE 154:2003, maintenance factor of luminaries is formed by the product of more than one indicators of performance [4-6]. MF depends on protection classes of the luminaries against contamination (IP65), sources of light used on luminaries and all effects which can cause decreasing the illumination.

\section{Illumination level}

Proportion of flux blazing through a lamp that affects the optic is luminous flux. Its unit is lumen and it represents ability of radiation to stimulate sense of radiance. As for total luminous flux, it is described as the sum of luminous fluxes arising from a source and spreading over various parts of the space. It is measure of light energy. In other words, total output from a lamp is defined by lümen [7-9]. The more lumen is high, the light is seen as clearer (1 lumen=0.00146 W).

Total luminous flux falling within unit surface is defined as illumination level of that surface and it is represented by E [10-14]. Its unit is lux. Radiant power of a lux is equal to a candle light. Illumination level belonging to point $\mathrm{P}$ and geometrical representation of illumination level of a point is illustrated on Equation 1 and Figure 2, respectively.

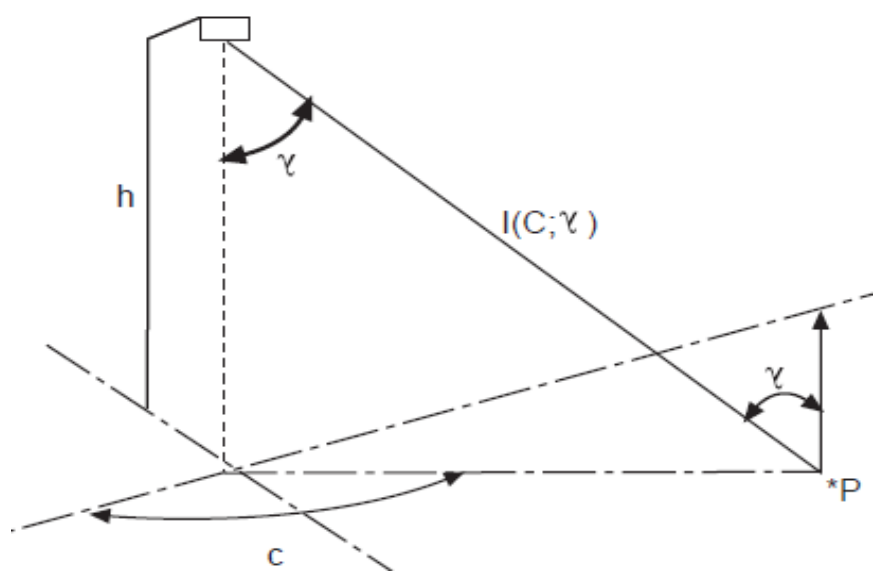

Figure 2. Geometrical representation of illumination level of a point 


$$
E_{P}=\sum_{i=1}^{a} \frac{I(C, \gamma)}{h^{2}} \cdot \cos ^{3} \gamma
$$

Where,

$E_{P}$ : Illumination level for point $\mathrm{P}$

$I(C, \gamma)$ : is value of light intensity reaching from luminaire i to point $\mathrm{P}(\mathrm{cd})$,

$\gamma:$ is angle of gleam falling within point $\mathrm{P}$ by the vertical line,

$a$ : is amount of luminaires contributing to point $\mathrm{P}$,

$h$ : is ground clearance of luminaire photometric center (m)

$C:$ is plane angle.

For luminaires, MF is defined as proportion of total light coming from luminaire at the end of maintenance period to total light of the luminaire during the primary use. If initial luminous flux of 5000 Lumens of a luminaire drops to 4000 Lumens one year later, maintenance factor is $80 \%$ for one-year maintenance factor of that luminaire.

In accordance with standards associated with the use of maintenance factor in lighting, lighting system is specified by the chosen lighting equipment, environmental conditions and the maintenance factor calculated for a specified period of maintenance CIE 154:2003. According to CIE 154:2003, lighting performance should not drop below minimum levels specified in the standards [4-6].

MF consists of Lamp Lumen Maintenance Factor $(L L M F)$ is proportion of performance loss in the lamp, luminous flux at the end of specified period, to the initial luminous flux. LLMF value is reached by catalogue of the manufacturer.

Lamp Survival Factor $(L S F)$ is the percentage of lamp survival ratio for maintenance factor. $L S F$ value is reached by the catalogue of lamp.

Luminaire Maintenance Factor $(L M F)$ is proportion of luminous flux, which decreases at the end of described/specified period as a result of structural feature of luminaire and also environmental factors, to the initial luminous flux. $L M F$ depends on protection class of luminaire against contamination (IP) and environmental pollution. It is specified by the designer according to contamination condition of the environment during maintenance period or the relevant specification is consulted. $M F$ is calculated according to equation 2 .

$$
M F=L L M F \times L S F \times L M F
$$

In the standard concerning calculation of lighting performances, $M F$ is formed by the product of luminous flux $M F$ and luminaire $M F$. Equation 3 demonstrates the relationship between $M F$ and Lighting Level [1, 8-10, 13].

$$
E=\frac{I \cdot \cos ^{3} \varepsilon \cdot \Phi \cdot M F}{h^{2}}
$$

\section{Determination of Maintenance Factor for HPS Lamp Luminaires}

High-pressure sodium vapor (HPS) lamps are preferred under conditions of higher luminance level, including under water tunnels, as HPS lamps have higher light flux and smaller dimensions than lowpressure lamps. As a result, less luminaries and area are required for lighting. Lighting efficiency (in terms of electricity consumption) of a similar lighting system increases up to $90 \%$ with HPS lamps compared to fluorescent lamps based on results obtained from various tunnels with different structures that are open to vehicular traffic [15-24]. The luminance efficiency is defined as the luminance level from the power required for the tunnel (for $1 \mathrm{~m}^{2}$ ).

In this study, HPS $100 \mathrm{~W}$ lamp luminaires inserted dually $6 \mathrm{~m}$ high are used in the tunnel. Maintenance factor for high pressure sodium vapor (HPS) lamp luminaires is specified by the product of three main factors described above. Determination of maintenance factor for a 100 W HPS lamp 
luminaire with protection class IP65 is calculated numerically. Figure 3 illustrates sample tunnel lightings [25].

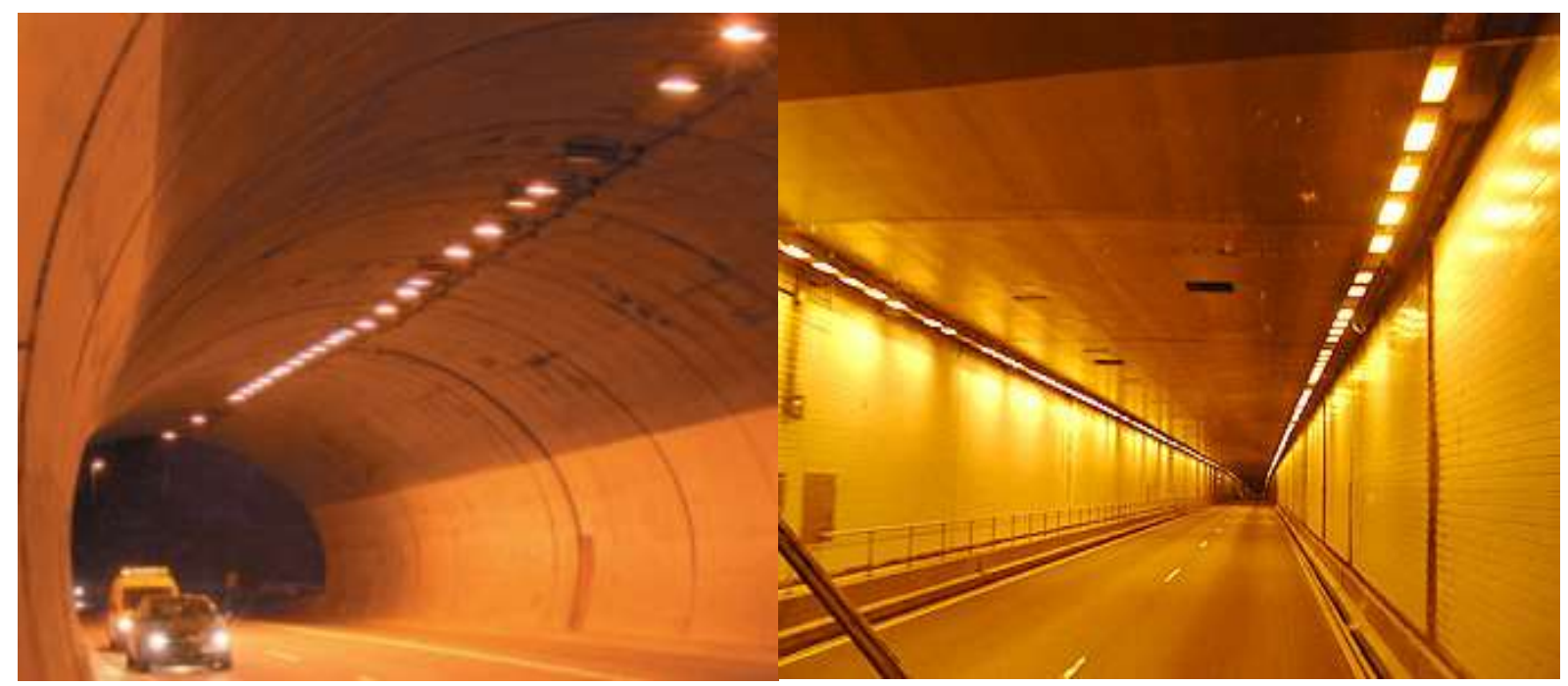

Figure 3. Sample tunnel lightings

\subsection{Luminaire Maintenance Factor Depending on Contamination}

Time intervals for maintenance (glass cleaning of the luminaire) should be specified by pollution level of the environment where lighting system will be installed for tunnel lighting. According to the principal of maintenance every other year and environmental conditions with high level of pollution, luminaire maintenance factor $(L M F)$ depending on contamination of a luminaire with protection class IP65 is specified as 0.91 over the table included in report CIE 154. LMF according to protection class of luminaire and category of environmental pollution is illustrated in Table 1.

Table 1. Table type styles luminaire maintenance factor by protection class of luminaire and category of environmental pollution

\begin{tabular}{ccccccc}
\hline \multirow{2}{*}{$\begin{array}{c}\text { Optical Compartment } \begin{array}{c}\text { Exposure time (Years) } \\
\text { IP Rating }\end{array} \\
\text { Pollution }\end{array}$} & \multicolumn{5}{c}{} \\
\cline { 3 - 7 } Category & & 1.0 & 1.5 & 2.0 & 2.5 & 3.0 \\
\hline \multirow{2}{*}{ IP2X } & High & 0.53 & 0.48 & 0.45 & 0.43 & 0.42 \\
& Medium & 0.62 & 0.58 & 0.56 & 0.54 & 0.53 \\
& Low & 0.82 & 0.80 & 0.79 & 0.78 & 0.78 \\
\hline \multirow{2}{*}{ IP5X } & High & 0.89 & 0.87 & 0.84 & 0.80 & 0.76 \\
& Medium & 0.90 & 0.88 & 0.86 & 0.84 & 0.82 \\
& Low & 0.92 & 0.91 & 0.90 & 0.89 & 0.88 \\
\hline \multirow{3}{*}{ IP6X } & High & 0.91 & 0.90 & 0.88 & 0.85 & 0.83 \\
& Medium & 0.92 & 0.92 & 0.89 & 0.88 & 0.87 \\
& Low & 0.93 & 0.93 & 0.91 & .090 & 0.90 \\
\hline
\end{tabular}

\subsection{Lamp Lumen Maintenance Factor}

Decrease in luminous flux depending on operating time of the lamps is reached by catalogue of producing company. Figure 4 presents the graphic reached by the catalogue of the producing company displaying performance loss of 100 W HPS lamps, depending on operating time, which supply lighting in the tunnel for 24 hours. Decrease in luminous flux is determined as 6\%,10\% and 13\%, respectively, at the end of operating times 1 year (8766 hours), 2 years (17532 hours) and 3 years (26298 hours), respectively. Figure 4 displays the decrease in luminous flux depending on operating time of $100 \mathrm{~W}$ HPS lamps. 


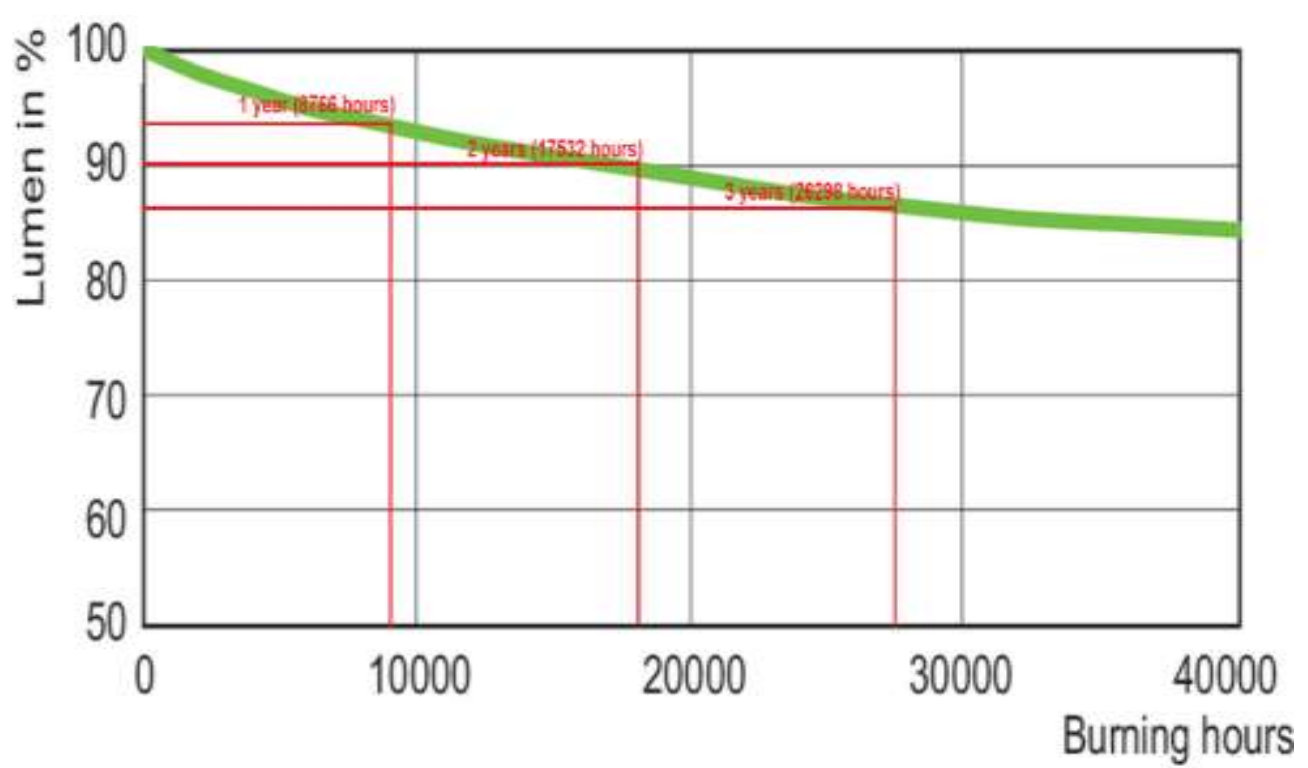

Figure 4. Decrease in luminous flux depending on operating time of $100 \mathrm{~W}$ HPS lamps [25]

Within this frame, maintenance factor depending on operating time of the lamps are determined as shown in the following for replacing periods of the lamps for 1 year, 2 years and 3 years: $L L M F_{(\text {lyear })}=0.94$, $L L M F_{(2 \text { year })}=0.90$ and $\left.L L M F_{(3 \text { year }}\right)=0.87$.

\subsection{Lamp Survival Factor}

It is required to determine LSF for three different maintenance periods through survival lines declared by producers of the lamps. In operation strategy, $L S F=1$ is accepted in case each attenuated lamp is replaced as soon as possible. However, since it is not possible to replace the far and wide broken lamps in a short time in general lighting applications, lamps are replaced periodically and collectively. All lamps are replaced in a period of attenuation by $10 \%$ in an area where $10 \%$ is accepted as maximum ratio of the prescribed attenuation of lamps to replace lamps collectively. Figure 5 displays the Line of lamps survival factor for $100 \mathrm{~W}$ HPS lamps.

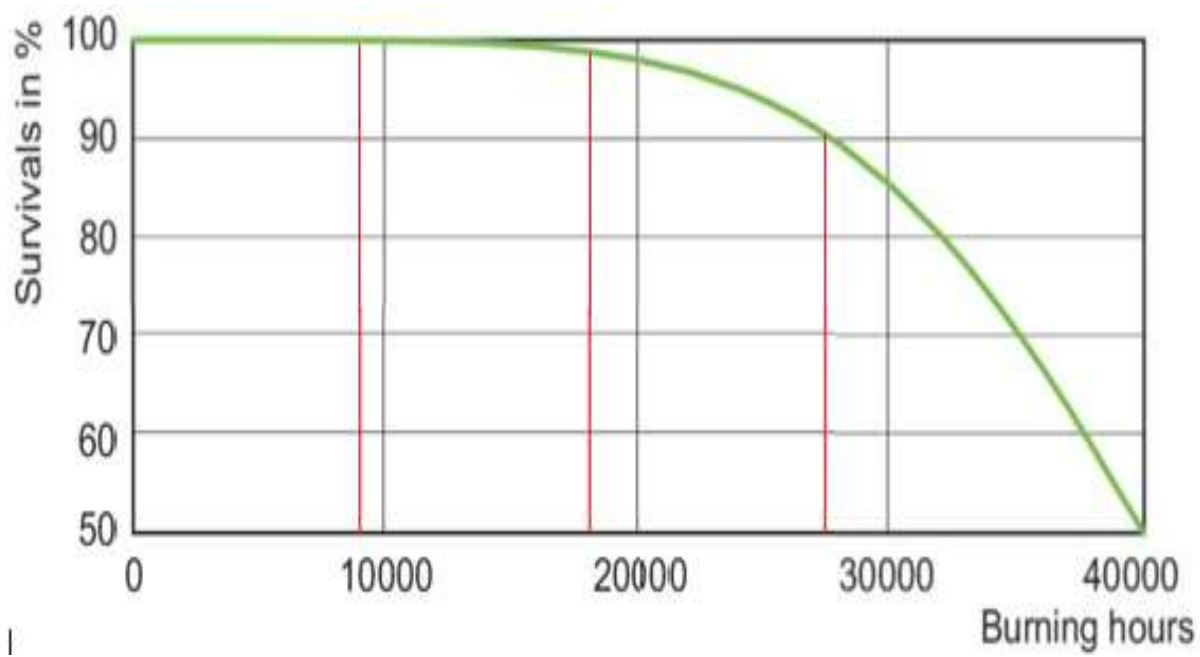

Figure 5. Line of lamps survival factor for $100 \mathrm{~W}$ HPS lamps [25]

From the graphic above, $L S F$ is determined as the following for replacing periods of the lamps in 1 year (8766 hours), 2 years (17532 hours) and 3 years (26298 hours) depending on operating time of the lamps in interior zone of the tunnel: $L S F_{(\text {lyear })}=0.99, L S F_{(2 \text { year })}=0.98, L S F_{(3 \text { year })}=0.90$.

According to lamp survival line, $10 \%$ of attenuation rate occurred after 3 year. Lamps with $10 \%$ of attenuation ratio demonstrate that it is not possible to use them more than 3 years. 


\subsubsection{Calculation of Maintenance Factor}

Variable MF can be calculated for various maintenance periods by using coefficients determined by all these details and clarifications. According to years, the $M F$ calculation is shown in equations 4,5 and 6.

$$
\begin{aligned}
& M F_{(2 / 1 \text { year })}=L M F_{(1 \text { year })} x L L M F_{(1 \text { year })} x L S F_{(1 \text { year })}=0.91 x 0.94 x 0.99=0.8468 \\
& M F_{(2 / 2 \text { year })}=L M F_{(1 \text { year })} x L M F_{(2 \text { year })} x S F_{(2 \text { year })}=0.91 x 0.90 x 0.98=0.8026 \\
& M F_{(2 / 3 \text { year })}=L M F_{(1 \text { year })} x L M F_{(3 \text { year })} x L S F_{(3 \text { year })}=0.91 x 0.87 x 0.90=0.712
\end{aligned}
$$

\section{Results and Discussion}

Accordingly, when equation 4, 5 and 6 is examined; of luminaire.

- While MF decreases to $84.68 \%$ at the end of $1^{\text {st }}$ year, $M F$ increases to $91 \%$ by cleaning glasses

- While MF decreases to $80.26 \%$ at the end of $2^{\text {nd }}$ year, $M F$ increases to $88 \%$ by cleaning glasses of luminaire.

- While MF decreases to $71.25 \%$ at the end of $3^{\text {rd }}$ year, all lamps should be replaced as the cleaning glasses of luminaire is not sufficient. All lamps were changed since decrease in illumination level couldn't be tolerated as a result of decrease in luminous flux at the end of $3^{\text {rd }}$ year of $M F$.

- The average illuminance $\left(E_{\text {average }}\right)$ represented by red in Figure 6 decreased gradually. While Eaver started with $100 \%$ in 1st year, it went down below $91 \%$ and $88 \%$ in $2^{\text {nd }}$ and $3^{\text {rd }}$ year, respectively. Accordingly, lamps operated for 24 hours in tunnel lighting should ben changed collectively at the end of $3^{\text {rd }}$ year.

According to these results, the following comments can be made:

a) In case of cleaning glasses of luminaires every 1 year and replacing all of the lamps in $3^{\text {rd }}$ year, it is seen that illumination more than by $40.35 \%$ will be required in case illumination level to be supplied at the end of period is reached up to $100 \%(1 / 0.7125=1.4035)$ for this lighting system.

b) In case of cleaning glasses of luminaires every 1 year and replacing all of the lamps in $2^{\text {nd }}$ year, illumination more than by $24.6 \%$ will be required $(1 / 0.8026=124.6)$ for this lighting system. In terms of energy consumption, it is seen that changing the lamps every 2 years is more advantageous by $6.5 \%$ than changing them every 3 years.

In that, illumination level in interior zone of the tunnel is required to be more than 124.6 rather than 100 since it is understood that illumination level of the lamps will decrease from $24.6 \%$ to $100 \%$ at the end of 1-year period. If tolerance margin of $24.6 \%$ in question is not left, then illumination deficiencies could cause accidents as they affect adversely visual comfort in the tunnel.

c) In case all of the lamps every 1 year, illumination more than by $18.1 \%$ will be required $(1 / 0.8468=1.181)$ for this lighting system. In other words, illumination level supplied by lighting in interior zone is required to be 118.1 rather than 100 in design of tunnel lighting since it is understood by this calculation that illumination level will decrease from $118.1 \%$ to 100 at the end of 1 -year period. If tolerance margin of $18.1 \%$ in question is not left, then illumination deficiencies could cause accidents as they affect adversely visual comfort in the tunnel. In terms of energy consumption, it is seen that changing the lamps every 1 year is more advantageous by $6.5 \%$ than changing them every 2 years and by $22.25 \%$ than changing them after 3 years.

\section{Conclusion}

It is critical to calculate properly $M F$ in order to install lighting systems of road pursuant to the purposes and maintain the performance to meet the expectations even at the end maintenance period or operating time of the system.

$M F$ takes an important part in total cost of a lighting system since it affects directly energy consumption. It is required to determine which one of these options are more economic depending on energy consumption, and cost of lamps and changing lamps. 
Start-up costs and maintenance costs of the systems should be considered to compare energy efficiency.

Increasing the maintenance factor used as multiplier in performance calculations increases the energy efficiency by decreasing the energy consumed.

In order to maintain routine maintenance activities, in the first scenario, once a year cleaning and at the end of 3 years all lamps are replaced. Brightness level should be $40.35 \%$ tolerance. The required illumination level should be approximately $1.40 x E$. In the second scenario, once a year cleaning and 2 years after the replacement of all lamps; The luminance level should be $24.6 \%$ tolerance. The required illumination level should be approximately $1.24 x E$. For periods of 2 and 3 years, replacing the lamp every 2 years is $6.5 \%$ more advantageous than every 3 years. Lighting deficiencies for both scenarios can cause accidents as they negatively affect visual comfort in the tunnel.

In the first scenario, provided that all lamps are replaced after 1 year, brightness level should be $18.1 \%$ tolerance. The required illumination level should be approximately $1.18 x E$. In case of cleaning and replacement of each lamp every 1 year, more than $18.1 \%$ of lighting will be achieved for this lighting system.

In terms of energy consumption, it is seen that replacing the lamp every 1 year is $6.5 \%$ more advantageous than the change every 2 years and $22.25 \%$ more than the change every 3 years.

\section{References}

[1] Cengiz M.S., Cengiz Ç. 2018. Numerical Analysis of Tunnel LED Lighting Maintenance Factor. IIUM Engineering Journal, 19 (2): 154-163.

[2] Eren M., Kaynakl1 M., Yapici I., Gencer G., Yurci Y., Cengiz M.S., Cengiz Ç. 2017. Numerical Analysis of Maintanance Factor for Tunnel and Road In Solid State Lighting. In: International Conference on Multidisciplinary, Science, Engineering and Technology 2017, Bitlis, 2017, October 27-29, Turkey.

[3] Gencer G., Eren M., Yildirim S., Kaynaklı M., Palta O., Cengiz M.S., Cengiz Ç. 2017. Numerical Approach to City Road Lighting Standards. In: International Conference on Multidisciplinary, Science, Engineering and Technology 2017, Bitlis, October 27-29, Turkey

[4] CIE Technical Report, CIE-88. 2004. Guide for the Lighting of Road Tunnels and Underpasses $[\mathrm{R}]-2004$

[5] CIE Technical Report, CIE-154. 2003. The Maintenance of Outdoor Lighting Systems.

[6] CIE Technical Report, CIE-194. 2011. On Site Measurement of the Photometric Properties of Road and Tunnel Lighting.

[7] Efe, S.B. 2018. UPFC Based Real-Time Optimization of Power Systems for Dynamic Voltage Regulation. CMES, 116 (3): 391-406.

[8] Cengiz M.S., 2019. The Relationship Between Maintenance Factor and Lighting Level in Tunnel Lighting. Light \& Engineering, 2019: 27 (3).

[9] Cengiz M.S. 2019. A Simulation and Design Study for Interior Zone Luminance in Tunnel Lighting. Light \& Engineering, 27 (2): 42-51.

[10] Çıbuk M., Cengiz M.S. 2019. Determination of Energy Consumption According to Wireless network Topologies in Grid-Free Lighting Systems. Light \& Engineering, 27.

[11] Cengiz M.S., Cengiz Ç. 2018. Numeric Analysis for the Efficiency of LED and Traditional Luminaries used in Tunnel Lighting. International GAP Renewable Energy and Energy Efficiency Congress, 10-12 May 2018, Şanlıurfa, 347-348.

[12] Cengiz M.S., Cengiz Ç., Mamiş M.S. 2018. Contribution of Reflector Design formed by Numeric Calculations to Energy Efficiency. International GAP Renewable Energy and Energy Efficiency Congress, 10-12 May 2018, Şanlıurfa, 349-350.

[13] Özkaya M. 1994. Aydınlatma Tekniği, Birsen Yayınevi, İstanbul.

[14] Tetri, E., Chenani, S.B., Rasanen R.S. 2018. Advancement in Road Lighting. Light \& Engineering, 26 (1): 99-109.

[15] Cengiz M.S. 2014. Evaluation of Smart Grids and Turkey. Global Advanced Research Journal of Engineering Technology and Innovation, 3 (7): 149-153.

[16] Efe S.B. 2015. Harmonic filter application for an industrial installation. Engineering of Modern Electric Systems 2015 13th International Conference on, Oradea, Romania, 11-12 June 2015. 
[17] Cengiz M.S. 2013. Smart meter and cost experiment. Przeglad Elektrotechniczny, 89 (11): 206209.

[18] Iacomussi Rossi G., Soardo P. 2012. Energy Saving and Environmental Compatibility in Road Lighting. Light \& Engineering, 20 (4): 55-63.

[19] Van Bommel W., Van Den Beld G., Van Ooyen M. 2003. Industrial Light and Productivity. Lighting \& Engineering, 11 (1): 14-21.

[20] Cengiz M.S. Mamiş M.S. 2015. Endüstriyel tesislerde verimlilik ve güneş enerjisi kullanımı. VI. Enerji Verimliliği Kalitesi Sempozyunu ve Sergisi, 21-25. 4-6 Haziran 2015, Sakarya, Türkiye

[21] Cengiz M.S., Mamiş M.S. 2015. Solution Offers For Efficiency and Savings in Industrial Plants. Bitlis Eren University Journal of Science and Technology, 5 (1): 24-28.

[22] Cengiz M.S. 2019. Efficiency Relationship of LED Parameters in Solid State Lighting. Bitlis Eren University Journal of Science and Technology, 9 (1): 22-26.

[23] Barua P., Mazumdar S., Chakraborty S., Bhattacharjee S. 2018. Road Classification Based Energy Efficient Design and its Validation for Indian Roads. Light \& Engineering, 26 (2): 110-121.

[24] Peña-García A., Gil-Martín L.M. 2013. Study of pergolas for energy savings in road tunnels, Comparison with tension structures. Tunnel. Undergr. Space Technology, 35 (1): 172-177.

[25] Master Son-T Apia Plus-Xtra, HPS-100, 2019. http://www.lighting.philips. com/main/prof/ conventional-lamps-tubes/high-intensity-discharge-lamps/son-highpressure-sodium/master-sont-apia-plus-xtra/928150219230_EU/product, (Access date: 04.05.2018). 